\title{
Understanding women's accommodation experiences on girlfriend getaways: A pragmatic action research approach
}

\begin{abstract}
In the realm of women's travel, while the accommodation experiences and preferences of female business travellers have been investigated, little is known about the female leisure-traveller in this regard. This study investigates one of the growth sectors in women's travel - girlfriend getaways (GGAs), which are holidays taken by females with other females. An action research approach was employed to explore the accommodation needs of these all female travel groups in the Malaysian context. Using a five stage approach which included in-depth interviews, a hotel-stay for three groups of women on a GGA, focus groups and secondary data analysis, four themes were identified. These themes address feminine comforts, facilitating friendship, safety, and shopping and the use of discount promotions with GGA. Findings suggest that the needs of female leisure-travellers are distinct from those of women who travel on business. Recommendations for hotel management are made to enhance the GGA experience for women, notably providing spaces and activities to facilitate female bonding.
\end{abstract}

Keywords: women's travel, girlfriend getaways; action research; accommodation preferences; hotels; safety; friendship 


\section{Introduction}

Since the mid-1990s, researchers have focused on the experiences of women in tourism either as workers (Aitchison, Reeves, \& Jordan, 1998; Sinclair, 1997), tourists (Anderson \& Littrell, 1995; Butler, 1995), or marketing images (Kinnaird \& Hall, 1996). Starting from a point where women were virtually invisible in tourism research (Swain, 1995), a body of knowledge has slowly grown documenting various aspects of women's experiences with tourism. Studies of women as solo travellers (Jordan \& Gibson, 2005; Wilson \& Little, 2005), women as tourists within the family context (Davidson, 1996; Deem, 1996; Small, 2005), women engaged in romance (Jeffreys, 2003; Pruitt \& LaFont, 1995; Taylor, 2001), and more recently in relation to sex in tourism (Berdychevsky, Gibson, \& Poria, 2013) have provided insights using a gender aware framework as advocated by Kinnaird and Hall (1994). Gibson Berdychevsky and Bell (2012) focused on a growing trend in women's travel that of the Girlfriend Getaway (GGA). Gibson, et al. found that the composition of these travel parties can include groups of female friends, mother-daughter trips, or other female relatives. Some trips are planned to mark special occasions such as pre-wedding, graduation or transitions to less pleasant life events such as divorce or widowhood, or they can be organized just for the chance to catch up and spend time with friends and/or female relatives. Such trips promote female bonding, opportunities to escape every day roles and responsibilities and are linked to health and well-being (Berdychevsky, Gibson \& Bell, 2013). Recently, Khoo-Lattimore and Prayag (2015) reinforced the growing popularity of all female pleasure-travel groups as a global phenomenon in women's travel.

Travel among women in general has given rise to a range of travel books and websites such as Marybeth Bond's "50 Best Girlfriends Getaways in North America" which help guide travel planning for all-women vacations. However, in the academic literature, we know very little about what women seek in their trips from the supply point of view. Most of our current knowledge has explored behaviour, motivation and experience often with little attention to accommodation related concerns, especially from a gender aware perspective. This is most surprising considering the substantial amount of work that has focused on consumer choice of lodging and accommodation services. Within marketing and consumer behaviour, most studies investigating hotel-related issues have focused on identifying service quality (e.g., W.-J. Chen \& Chen, 2014; 
Lee, Jeong, \& Choi, 2014) along with guest satisfaction (e.g., Abbasi, Khalid, Azam, \& Riaz, 2010; Albayrak \& Caber, 2015; Zhou, Ye, Pearce, \& Wu, 2014) and guest loyalty (e.g., Enriquez-Magkasi \& Caballero, 2014; Kandampully \& Suhartanto, 2000; Malik, Naeem, \& Nasir, 2011; Wilkins, Merrilees, \& Herington, 2009). As such, many researchers interested in accommodation related issues have tended to concentrate on identifying and ranking hotel attributes (e.g., Albayrak \& Caber, 2015; Choi \& Chu, 2001; Huertas-Garcia, Laguna García, \& Consolación, 2014; Mccleary, Weaver, \& Hutchinson, 1993; Stumpf, Park, \& Kim, 2014). In doing so, researchers have applied various consumer theories to different lodging categories including budget properties (Nash, Thyne, \& Davies, 2006; Zhang, Ren, Shen, \& Xiao, 2013), luxury accommodation (A. Chen \& Peng, 2014; Ekiz, Khoo-Lattimore, \& Memarzadeh, 2012; Khoo-Lattimore \& Ekiz, 2014; Lau, Akbar, \& Yong, 2005; Mohsin \& Lockyer, 2010), apartments and bed and breakfasts (L.-C. Chen, Lin, \& Kuo, 2013; dos Santos, Chaves, \& Pedron, 2014; Jones \& Guan, 2011), but researchers have tended not to examine how these types of accommodation are suited to particular types of guests, such as women engaged in leisuretravel. In addition, a majority of these studies were conducted from the perspective of benefits sought by customers and therefore not focused on investigating customers' preferences for specific hotel offerings. Thus, the purpose of this study was to examine the accommodationrelated needs of girlfriend getaway participants, with a view to enhancing our knowledge about women's hospitality-related preferences in the leisure-travel context.

\section{Review of Literature}

\section{Women as tourists}

Women as tourists have been approached by researchers primarily from two perspectives: a socio-cultural/behavioural focus and a marketing focus. From the socio-cultural viewpoint, much of the early writing referred to examples of Victorian women as pioneers of the modern day female tourist (Birkett, 1989; McEwan, 1996; Robinson, 1990; Smith, 2013). These intrepid women, imbued with the contradictions of class, privilege and gender set off on quite arduous journeys despite the frequent disapproval of their family and society more generally. As such, this set the foundation for the investigations into women's experiences of solo travel (Gibson \& Jordan, 1998; Jordan \& Gibson, 2005; Wilson \& Little, 2005, 2008) and the current work on 
GGAs (Berdychevsky, et al., 2013; Gibson et al., 2012; Khoo-Lattimore \& Prayag, 2015) . The consistent themes in these studies are that travel is both experienced as empowerment and resistance, but also takes place in a gendered context (Swain, 1995) which often means negotiating issues of risk and safety. Indeed, in work of relevance to the current study, Catterall, Maclaran, and Stevens (2000) found that women travellers are particularly concerned with hotel security measures when choosing accommodation.

In the women as tourist research that adopted a marketing focus, one of the earliest investigations examined working and non-working women's travel patterns using a life stage perspective (Bartos, 1982). Her findings mirror much of what we still see today, that women with small children tend to travel less, that working women travel more often, and single and childless women travel abroad more frequently. In another early study, Hawes (1988) examined the travel patterns of women aged 50 and older using psychographics and distinguished three travel profiles, the experienced, the laid back, and the dreamer. Similar to the work on the Victorian women travellers, Hawes found that many of these middle aged women were active and adventurous tourists. Similarly, Kerstetter and Pennington-Gray (1999) using a benefits sought perspective to examine the travel preferences of middle class women also found a range of travel styles.

Not surprisingly, one of the key messages in the women as tourists literature is that while there are some consistent patterns such as the influence of life stage and the presence of children or a concern over safety, women are also heterogeneous in their travel preferences. In terms of inter gender differences, scholars have found that men and women select tourist destination and hotels using different criteria (Ryan, Henley, \& Soutar, 1998). Yet, little attention has been devoted to investigating the differences in needs between men and women in hospitality and tourism and even less work has explained these differences. Within the hospitality discourse, studies on female needs and wants have primarily focussed on the businesswomen (Brownwell, 2011; Chan, 2014; Harris \& Ateljevic, 2003; Lutz \& Ryan, 1993; McCleary, Weaver, \& Lan, 1994; Phadungyat, 2008; Sammons, Moreo, Benson, \& Demicco, 1999). Lutz and Ryan (1993) surveyed both male and female business travellers in the UK with the aim of identifying differences in perceptions about hotel services. Participants were asked to assess the desirability of general hotel facilities such as "hair dryers, hanging space, full-length mirrors; tea machines, 
the attitudes of staff; the handling of room allocation... where guests had their meals" (p. 351). Two sections of the questionnaire required only responses from the women as they pertained to attributes associated with female-only programmes offered by hotels such as security, womenonly floors and female rooms with "specific feminine décor and the provision of female toiletries" (p. 350). A majority of the 48 businesswomen surveyed considered women-only floors, female toiletries and feminine décor unimportant. The results showed few differences between male and female executives in their attitudes towards hotel provisions except females expressed the need for safe and secure car parking and to feel comfortable when having their meals in the hotel restaurants.

In contrast, McCleary et al. (1994) highlighted significant differences between male and female business travellers in terms of the criteria they used in selecting their hotels. They noted that men placed more priority on business facilities such as office space and fax machines while women were more concerned about room service, dead bolt door locks, peep holes, surveillance cameras, chain locks, bright hallways and parking area lighting. Sammons et al. (1999) in their study on 434 businesswomen also concluded with similar findings. The women in their survey rated women-only floor, feminine décor (such as pastel-coloured rooms) and female toiletries (bubble bath, nail polish remover) unimportant. Instead, they placed high importance on hotel cleanliness and security provisions such as dead bolt door locks, parking area lighting and chain latches on doors. Phadungyat (2008) also found that safety and security facilities', especially 'electrical keycards', 'bright hallways', 'sprinkler system', and 'closed circuit television' are important factors for businesswomen in their selection of serviced apartments (p. 45). Thus, the issue of safety and security seems to be a consistent finding across all of these studies on women and their accommodation preferences.

Another consistent theme across research on the needs and preferences of women travellers is the tendency to focus on the business traveller to the exclusion of the female leisure-traveller. This is likely attributable to the growth in the proportion of business travellers who are women from 25\% in 1991 to almost 50\% in 2010 (Brownell, 2011) and the various industry initiatives to meet their needs. While these studies have provided some key findings, it is also important to note that travel trends for women have changed in the $21^{\text {st }}$ century, with declining numbers for business travel but increases for pleasure travel (Warnick \& Chen, 2008). The decline in business trips 
could be attributed to the increasingly advanced mobile and communication technology which reduces the necessity for many corporate trips but not pleasure holidays. In addition, findings on female business travellers may be limited in their applicability to women travelling for pleasure. Indeed, Kashyap and Bojanic (2000) found that perceptions and expectations about value, quality and price differ significantly between business and leisure travellers. Thus, there is a gap in our understanding about the needs of the female tourist. Moreover, past studies on the female traveller have returned contradictory findings. For example, Sammons et al. (1999) noted that, 'Some women have expressed the preference for 'female only' floors and demand special treatment from hotels... (but hotel) properties have discovered...that women prefer not to be singled out for special treatment' (p.69). Part of this problem might be attributed to the stated preference approach scholars have frequently used to measure female guest perceptions, expectations and intentions (Marzuki, Chin, \& Razak, 2012). Stated preference methods aim to identify the utility functions that individuals use to make choices (Timmermans, Molin, \& van Noortwijk, 1994). In identifying these utility functions, respondents are typically presented with profiles (i.e. descriptions of relevant attributes) of hypothetical choice alternatives. They are then asked to express their preference for these profiles. This is particularly problematic as there is often a discrepancy between what people say they seek and what researchers identify as unspoken motives (Arnould \& Price, 1993). It can also be argued that the respondents do not have a good idea about their priorities and considerations until confronted with the actual offerings in a real setting. Studies of tourist behaviour have also shown in addition to this that there is a difference between indicated preferences and actual behaviour (see for example, (KhooLattimore \& Prideaux, 2013). Furthermore, there are also issues related to the ranking and rating of attributes in questionnaires that neglect important contextual and situational elements.

Thus, this study attempted to address these limitations. Without moving away from its aim to explore hospitality preferences for female leisure-travellers, we implemented an interpretive methodology based on the rationale that an emergent design was needed to document the actual experiences of GGA females staying in hotels. Specifically, the following questions guided this study: (1) What are the accommodation needs of women on girlfriend getaways?; and (2) What is the relationship between women's accommodation needs and the industry's provisions for them? 


\section{Method}

\section{Research design}

The purpose of this study was not only to develop an in-depth understanding of the ways women on girlfriend getaways interact with and experience hospitality products and settings, but to do so with the input from industry practitioners. This study was conducted with the cooperation and involvement of a new three-star boutique hotel located in the urban area of Subang Jaya, Malaysia, and four commercial businesses interested in understanding the viability of their products placed within the tourism servicescape.

The chosen research method is that of action research (Lewin, 1946), which is an approach that is committed to the production of new knowledge through the search for solutions or improvements to 'real-life' practical problem situations (Susman, 1983). This study involves 'real' women on actual girlfriend getaways in a 'real' hotel, and engages 'real' local stakeholders such as hotel managers and business operators. The decision to employ action research was to attain a naturalistic understanding of women's experiences on girlfriend getaways which would both add to the body of knowledge as well as provide practical suggestions for the hospitality sector. Action research is chosen because of its juxtaposition of action and research - of practice and theory (McKay \& Marshall, 2001). In general, there are two approaches to action research - the participatory (also known as the critical approach) and the pragmatic (Botterill \& Platenkamp, 2012; Reason \& Bradbury, 2001). While the critical approach is suited for research in contexts where 'unequal and invisible power relations' exist and transformative action is desired, the pragmatic is employed in situations where action is wanted and the 'power to act' is anticipated (Johansson \& Lindhult, 2008, p. 95). Susman (1983) describes pragmatic action research as 'a sociotechnical systems perspective' (p. 98) and involves understanding and developing a solution for practical problems in organizational settings. Although it is important to highlight here that there is no ideal form of action research (Greenwood, 2007; Stringer, 2013), this study adopts the pragmatic approach to action research. Considering the fledging stage of the GGA market, the industry's input was invaluable as to the necessity and relevance of the study hence the pragmatic approach was deemed to be necessary. 


\section{Data collection}

Data collection was guided by Susman's $(1978 ; 1983)$ five-phase model of the action research process.

\section{Phase one: Diagnosing}

The first phase was to identify the problem. This was done by compiling two lists. List one was generated from the academic research findings described in the literature review that has identified various components women seek from accommodation providers (e.g., hair dryers, hanging space, full-length mirrors, tea machines, women-only floors, female rooms, feminine décor, female toiletries, secure car parking, parking area lighting, dead bolt door locks, peep holes, surveillance cameras, chain locks, bright hallways, electronic key cards, sprinkler system, and closed circuit television). Scholars were focussed on assessing the importance of certain amenities and services such as cleanliness, restaurants, hotel location, friendly hotel staff, wellmaintained furnishings, bright hallway lighting, sanitary items, privacy and room attractiveness (Lutz \& Ryan, 1993; McCleary et al., 1994; Phadungyat, 2008; Sammons, et al, 1999). List two was generated from a review of the offerings provided by hotels that specifically provide services for female guests. In comparing the lists, it became apparent that many of the services and packages offered by the hotels were not detailed in academic research. The hotel offerings could well have covered the amenities described in academic literature but hotels also sold health, beauty and self-pampering facilities (spa, massage, hair salon), bathtub, extra-large shower head, powerful hand shower, make-up mirror with magnification, beauty supplies, fresh fruits, scented candle, fresh fruit, healthy snacks, a private shopping tour and free shipping for their purchases.

\section{Phase two: Action planning}

The second phase in the model of action research involves deliberating on possible courses of action. In keeping with Susman's (1978; 1983) advocacy for defining a research problem in collaboration with the research participants or what he called a diagnosis, 13 one-on-one interviews were conducted with women who travel for leisure to further explore and identify their hospitality needs and wants. The aim of these interviews was to compare what they say they need 
to the two lists. The women's ages ranged between 20 and 48 years. They were either pursuing or already had completed a tertiary education, and were all Malaysians, representing the three major ethnicities in Malaysia (Malay, Chinese and Indian). The data from these 13 women while not the primary focus of analysis for this study, yielded unique insights about women's travel preferences that were not present in the literature and industry review. For example, the interviewees talked about amenities and services that they would like to see in a hotel such as the availability of a variety of female magazines, branded toiletries, manicure collections, fresh flowers, shower caps, free wireless internet, and sufficient access to bottled water. The absence of the latter two amenities from the lists developed from the literature and industry sources are likely attributable to the fact that much of the research on female preferences for accommodation amenities was conducted in the 1990s, prior to the advent of Wi-Fi and bottled water. The women also mentioned the need not only for physical security, but a psychological sense of security. By this, they explained how they would like to explore areas around the hotel confidently without feeling lost. For example, the respondents described stress in having to scout for cafes, restaurants, shopping outlets and entertainment activities in a location they are unfamiliar with and upon having researched where to go, they experienced a small degree of anxiety in transportation choice. This anxiety centred on issues of driver trustworthiness and fare charges.

\section{Phase three: Action taking}

Consistent with the principles underlying Susman's $(1978 ; 1983)$ approach to action research, phase three requires that investigators find out more about the nature of what is referred to as the 'problem' and the problem context. In this study, the notion of problem was conceptualized in the research purpose, as the desire to understand the hospitality needs and wants of women on girlfriend getaways. As part of Susman's approach to action research, the researchers enter into a collaboration with the 'client system' (in this case, the women who go on girlfriend getaways) and engage them during the planning of a possible problem-solving strategy. In phase three, practitioners from the hotel industry were also engaged in the research process. The interview findings from the 13 women in phase two were discussed with five hotel managers. All five hotel managers acknowledged the rising trend of female guests and the need for female-friendly amenities, but had reservations for implementing immediate changes in their properties. Their reservations are largely attributed to an under-researched market and its associated return on 
investment. The managers admitted to adopting the 'wait-and-see' strategy, that is, observing what others do that are successful before duplicating them.

Susman (1983) explains that a key and necessary component of a pragmatic approach to action research is a commitment by the researchers to not only plan possible problem-solving strategies, but to actually 'take action', and to improve the problem they are researching. Driven by the reservations expressed by the hotel managers and the discrepancy between what consumers say they want and what they actually purchase, the 'taking action' third phase of this study consisted of a two-day-one-night stay for 12 women in an operational hotel (i.e. a real hotel). The following section details the stay and data collection procedures for phase three. The discussion with hotel managers and this round of data collection reflect the spiral process of phased stages, which loops continuously for as many times as is needed to conclude the research.

For phase three, 12 participants were recruited via a message on Facebook about a competition to win a two-day-one night girlfriend getaway for them and three female friends. The competition ran for approximately two weeks in February 2012 and was promoted to female-centred Facebook groups and pages in Malaysia (such as mothers' groups, women and women's magazines' pages) in an attempt to attract participants from diverse backgrounds. The tourism destination of Subang Jaya and the hotel choice were listed in the competition message. Interested participants were required to upload a photo of their most recent girlfriend getaway and submit a small paragraph on why they deserved to win the girlfriend getaway. The photo served as a criterion for participation to ensure that the women participating in the study had already taken at least one girlfriend getaway. All eligible and completed entries were filtered through a Facebook competition widget which chose the winners at random. Three winners were selected and they in turn selected three of their female friends to accompany them on the weekend getaway. The 12 women were accommodated in six rooms in a hotel located in the city centre of Subang Jaya, Malaysia. Thus far, the data collection phases addressed Carson, Gilmore, Perry, and Gronhaug (2001)'s techniques for establishing trustworthiness of qualitative findings. Namely, this is a field-based study and data were collected in natural setting for GGAs. Secondly, we used purposive sampling where the women were chosen because of their relevance to the experiences investigated in this study. We also triangulated data from the focus groups with the two lists we generated, industry managers and the 13 women in phase two. 
Following recommendations from the data collected in phases one and two (the two amenity lists, the 13 interviews and the discussions with 5 hotel managers) the hotel rooms were equipped with women-specific amenities. For example, reflecting the women's needs to feel secure physically and psychologically, the hotel managers suggested the implementation of a 'security' card. Thus, in phase three a card containing the telephone number connecting the women directly to the hotel's security personnel was placed next to the guest-room's telephone. This card also provided the women with information about places of interest in the hotel's vicinity, in particular the largest shopping complex closest to the hotel was listed. In addition, the rooms were furnished with manicure sets, scent diffusers, women's magazines, fresh flowers, and luxury brand bath amenities. Some retailers in the adjacent shopping complex were approached for cash vouchers and these were included in the room package. During their stay, the women in this study were also treated to in-room personal massages, an exclusive dinner by the lake, and a pre-arranged lunch at a Mediterranean restaurant in the shopping complex. The hotel also provided free transportation to the shopping centre, again this was in response to the interviews conducted in phase one where women expressed anxiety about being in an unfamiliar location. Providing all of these amenities and services was in line with the purpose of this study to understand the hospitality experiences of women travelling on girlfriend getaways in a 'real-life' hospitality context. The procedures used are also consistent with Susman's (1983) conceptualization of action research as directly involving research participants in the design and operation of the problem-solving activities.

\section{Phase four: Evaluating}

At the end of the two-day-one night stay and upon checkout, the 12 women took part in one of three focus groups aimed at encouraging a group-based synergistic discussion about their experiences during their stay. The timing of the focus groups was important as recentness of the event was crucial in ensuring that the information and feedback captured was as accurate as possible. The focus groups are part of what Susman (1983) identified as phase four of the action research process and involve the evaluation or analysis and interpretation of the data to determine how successful the action had been. The three focus groups were conducted concurrently by three separate facilitators using the same semi-structured interview guide. Prior to the interview sessions, all facilitators were briefed on the scheme of questions that were to be asked and the 
main aim behind the questions. Broad general questions were asked such as: Which part of this getaway did you like/not like/feel can be improved? Was this weekend getaway able to meet your group's need and wants? If so, how and if not, why not? Did the weekend getaway exceed expectations? If so, how? If not, why not?' Interview questions also focused on the specific actions that were implemented in the hotel so if participants had not articulated any of the actioned amenities after the general questions, they were also asked, 'How did you find the security card/toiletries/the scent diffuser etc.?'

\section{Phase five: Specifying learning}

Susman's $(1978 ; 1983)$ five phase model of action research culminates in what he explained as the phase for specifying learning, a phase where the general findings are identified. Video and audio recordings of the focus groups were made. The video recordings were not treated as data per se, rather, they were mainly used to identify speakers when background noise made it impossible to do so merely through the audio recordings. The video recordings also eliminated the need for the interviewers to take detailed notes during the focus group discussions. Audio recordings of the interviews were transcribed verbatim. Constant comparative analysis was conducted involving open and axial coding (Scott, 2005; Strauss \& Corbin, 1990). Comparisons were first made within one focus group interview, then across focus groups' interview transcripts. Comparisons were also made between interviews and researcher observations and notes (Boeije, 2002). All of the empirical material was divided into meaningful units and categories (Jennings, 2010) and in the final stage of analysis, inductive codes were developed and emergent themes were identified.

In line with Susman's (1983) action research method, our research process was democratic: in that consumers and practitioners were actively involved throughout the research process. Thus, following analysis of the data, the preliminary findings from this study were presented to the key industry stakeholders (the participating hotel and four commercial businesses) and at two separate industry events for hotel managers where members of the Malaysian Association of Hotels were present. The rationale for these presentations was to engage with relevant industry practitioners drawing upon their expertise and to co-create a body of collective knowledge that could be used to advocate for change in the way hospitality products for women are currently offered. The majority of the practitioners expressed appreciation for the study and while a few 
were concerned about the financial feasibility of any new implementations, many were receptive to the potential of adjusting current offerings to cater to the GGA market. These presentations and the discussions that ensued, echoes (Carson et al., 2001)'s advice for establishing trustworthiness (debriefing by peers to help researchers search out what they have seen or heard) but also led to cyclical phases of data analysis. Four overall macro themes related to the hospitality needs and issues experienced by the women during girlfriend getaways were identified.

\section{Participant profile}

The 12 participants from phases three through five were aged between 22 and 42 years (Table 1). Because people tend to be friends with others who are similar in age, this resulted in a situation where the focus groups were segmented by age. Focus group one was comprised of three women in their 30s and one in her early 40s; focus group two comprised one woman in her mid-20s; two women in their late 20s and one in her mid-30s; focus group three consisted of four friends in their early 20s. All 12 participants were Malaysians, albeit from three major ethnic groups, seven were Malaysian Chinese, three Malaysian Indians and two Malays. Most of the participants were single $(n=10)$, one was married and another was divorced. Three of the respondents were tertiary level students while the remaining nine were employed. With regards to education level, three were pursuing a degree, seven had completed a degree, one had pre-university qualifications and one had completed a postgraduate degree.

\section{[Insert Table 1 about here]}

\section{Findings}

\section{Appreciating the female amenities: Sugar and spice and everything nice}

The first theme identified in the data concerned the women's evaluation of the distinct amenities designed especially for women. When asked which element of the weekend getaway they liked the most, all 12 of the respondents cited the luxury brand bath products and the manicure and pedicure pampering sets. Referring to the bath products that had been secured through a sponsorship from L'Occitane, Veera, a 37 year old administrative executive said, 'You feel good using a brand that you know is very good. The hotel brand can be any lousy brand. We wouldn't 
know what the content of the [bath gel, shampoo or body lotion] is. With this [L'Occitane] at least you know that it's a quality product.' Likewise, 35 year old Sze Man commented that the bath products were a highlight of the getaway because L'Occitane is typically a brand that 'we can only afford to walk past ....and just stare at'. A majority of the respondents expressed appreciation for the fresh flowers and scent diffuser. Rika a 25 year old administrative executive was impressed with: 'The flowers....wowwww!' while 28 year old Smitha said the flowers 'greet you when you enter the room.' Azura a 27 year old administrative officer also thought the flowers were 'so special' and made the hotel stay feel like a 'VIP retreat.' All the women in the second focus group thought the scent contributed immensely to the ambiance of the room, and the feel of the getaway. For Smitha, the scent '...just makes you feel welcome and then you start feeling more relaxed when you enter the room and then it switches on this button for relaxation.' The female magazines were also applauded by the women in this study and Sharma, a 32 year old senior administrative executive, thought this alone contributed positively towards the getaway: 'It's really like a ladies retreat because ladies like doing all these, you know, looking at the magazines, flipping the pages...'

In general, the additional female-specific amenities included in the hotel rooms during this study seemed to have made a significant impression on the respondents. In summarizing the women's sentiments, Sharma said 'We were jumping [for joy]...really really felt pampered;' Smitha echoed her response and said 'There were lots of pleasant surprises along the way.' Stephanie, a 31 year old, said we 'We didn't expect this much...this [good] quality' and Ellie, a 22 year old student, felt that 'All these make a difference.' Indeed, Sharma felt that [the additional amenities] make a very good impression for the guest when they walk in. Azura noted that 'Never [have we] been treated this way before when entering the hotel...' something that Melissa, a 22 year old student, described as 'It's amazing.' So overall, the women appeared to be very impressed with the female oriented amenities and services provided by the hotel and they overwhelmingly felt that these not only created a good impression, but made them feel special.

\section{Reflections about the trip: Girls just want to have fun... and each other}

The second theme focused on the women's reasons for taking a girlfriend getaway. Sharma said one reason was 'get away from the hectic city life' and as Sze Man said 'to have fun with close friends.' Sharma further commented that 'When you do it with a group of girls it's so fun you 
know. We just do fun things.' 'Fun things' included sight-seeing, hiking, trekking, having barbeques, watching the sun set, shopping, food-hunting, attending flea markets, riding rollercoasters, island hopping, snorkelling and diving. Interestingly however, it seems as if doing any activity together was just as if not more important than the type of activity they chose to do. 'Fun' was conceptualized in the ways they spent time with one another. Ellie explained, 'Basically, we just plan our time together and we just go for the meals, maybe lunch then dinner and in between these [meal] times, we will go either in the hotel or if we are on the beach then we go to the beach.' For Azura, the getaway is 'how we grow closer to each other and we keep our bond' while Sze Man added, 'Well we just love having the company of one another, because we feel that we can click that's why the bonding session.'

The third group of women cited 'pillow talk' - chat sessions in the evening - as something they look forward to in every girlfriend getaway. Indeed use of the manicure and pedicure sets was often regarded as a chance to bond with each other. As Stephanie noted, '...those things that we have there help us to bond...like manicure and pedicure, it's really all of us doing it together, crazy stuff, so we were really having fun...' The dinner organized by the hotel for the women in this study was also welcomed as it facilitated a relaxed chat session over food with their girlfriends. The need to spend time with one another and the necessity of having the facilities to do so was something that the participants spoke about. An example, as Melissa proposed, is for hotels to provide rooms that 'must be big enough for us girls' to gather and chat in. Veera recommended that hotels could provide make-up kits with how-to leaflets as something they could do together in the room. Other suggestions that emerged from the study included extending swimming hours so they could utilize it not to swim, but to soak in and chat. Other ideas included novel group classes such as Zumba and kickboxing in the hotel gym and small closed off cosy areas where they could laugh without having to worry about waking up the guests next door.

\section{Need to feel safe: Safe travels}

The third theme focused on the safety and security of the hotel rooms. The participants voiced an appreciation for the aforementioned card which included the emergency telephone number for the security guards. Ping, a 42 year old, thought the security card, 'is very good because I've been to 
a lot of hotels where they don't have that kind of thing. They only basically tell you where you can get housekeeping. They don't...there's no mention of security.' Melissa concurred, saying, 'We feel more secure because at least we know whom to contact.' Azura added that having the card by the phone is a good idea because it is 'easier to just refer to it in case of emergency.' Further conversations with the women suggested that besides door latches, peep holes and an allfemale floor, hotels can do more to help women on vacations feel more safe. For example, Azura suggested that hotels catering to women groups could, 'call each room to make sure everybody is okay.' The findings also revealed that the provision of transportation can increase the women's sense of safety while on holiday. The availability of the car service that ferried them from and to the shopping complex in this study was deemed by the respondents to be very important. Melissa suggested that hotels wanting to target women guests should '...like maybe they can provide some transport to our destination.' Many hotels currently already offer this to their guests via regularly scheduled shuttle service to and from the airport, and sometimes to nearby town centres, but the women in this study discussed the need to extend this service to reliable and trustworthy transportation service catered specifically to their groups. Sze Man elaborated on this with an example from a past girlfriend getaway she went on where someone was designated to chauffer them around, 'The guy took us to the club. Yeah he's the organizer, I mean he will take us all in our group...' Her travel companion, Smitha supported this view, 'Yeah just to have somebody to look out for us, so that will be good.'

Only the second focus group discussed other safety amenities such as a chained door latch and peep holes. Rika said that because the door did not have a chained latch, '...last night I feel scared a little bit because it's quiet outside. So after this lady slept (referring to her roommate, Sze Man), I was just like... I'd better go check the door that kind of thing....I checked twice or three times'. Sze Man, did not seem concerned with the lack of chained door latch, but only because she had earlier ensured that the door does lock securely, 'And the latch, actually I think only our room doesn't have one but because I tried when I closed the door from the outside, nobody can actually open the door so fine, without the latch it's still okay'. Smitha who was in the same focus group then commented, 'I just want to add something. I think it's very important for the door to have at least a tiny peep hole so you can actually see who is at the door.' This group also suggested biometric fingerprint door locks as a means to improving safety and security measures for women in hotels. 


\section{Favourite activities: Shop till'you drop...not!}

The fourth theme focused on an activity the literature suggests women do most notably during their vacations, that is shopping (McGehee et al, 1996; Pennington-Gray \& Kerstetter, 2001; Smith \& Carmicheal, 2008). Indeed, when asked what they usually did during their girlfriend getaways, Veera said, 'Shopping would be part of it' and Azura added, 'Of course we love shopping.' Smitha provided reasons for why shopping during girlfriend getaways is particularly welcomed, 'Shopping is fun because you actually go together with your girlfriends and then you know you have each other have to choose each other's outfit so it was fun to go shopping together.'

As part of the research scenario, the hotel provided shopping cash vouchers from retailers in a nearby mall as part of the girlfriend getaway package. This offering however, had an opposite effect on the holiday experience to what was intended. For example, Stephanie complained that she did not get to use her cash voucher because, 'I don't really patronize this shop and I didn't see anything interesting.' Her travel companion, Veera grumbled that she was not free to use the voucher in the way that she wanted: 'Mine totalled to RM97 (approximately USD30), she (the cashier) said it's not enough (below the amount provided by the RM100 cash voucher) so they can't sell it to us. So I had to take another belt and then it came to RM110 [and I had to pay the RM10].' There were similar sentiments in the third group of women. They admitted that they would have preferred it if they could dictate where and how they spent their shopping vouchers, as indicated by Sharma's statement: 'If you give us discount voucher [from Forever 21] we will definitely take that instead of the cash voucher from ELLE...' The findings suggest that the shopping vouchers may have caused some level of stress and dissatisfaction for the women in this study, and subsequently affected the getaway.

Nevertheless, the interviews did provide additional insights into other forms of vouchers. Sharma said she would value vouchers for spa a treatment, while Veera concurred and mentioned vouchers for either a pedicure or manicure. Ping said she would welcome a meal voucher and many of the respondents echoed preferences for breakfast vouchers. For example, in the first focus group, when Veera said, '...the important thing would be the breakfast,' all three of her friends enthusiastically exclaimed, 'Yes!' For her friend, Sharma, 'The breakfast has to be there at the hotel.' Where meal vouchers are concerned, lunch and dinner vouchers are also 
mentioned, but only if the getaway extends more than one night as Ellie put it, 'If we go for four days three nights, then maybe they can provide one night ['s dinner] and the other nights we'll find our own food.' When Stephanie said, 'If there's a long stretch of five days like that maybe at least one meal is included', Veera agreed, 'Yeah like one dinner or something like that.'

\section{Discussion}

The four themes identified from the 12 women who took part in the hotel stay and the subsequent focus groups both confirm and provide new insights on the lists of amenities generated from the existing literature and industry provision (phase one), as well as the insights from the 13 women interviewed in phase two. The first two themes suggest that the provision of hotel offerings for female leisure travellers should emphasize the feminine comforts and assist in enhancing the overall desire of the women on girlfriend getaways to spend time together. The women who took part in the girlfriend getaway simulation were particularly appreciative of the additional amenities targeted at the female guest in their rooms. In particular, the women were impressed with the branded toiletries, the scented rooms, and the magazines. Interestingly, this finding contrasts with existing research on the female business traveller who rated such feminine comforts as largely unimportant (Lutz \& Ryan; 1993; Sammons et al, 1999). Perhaps the difference here between the two types of female traveller is the underlying purpose and motivation for the trip. When travelling for business, the instrumental functionality of a hotel for achieving work-related objectives may be more important, whereas, for a leisure-trip which connotes relaxation, escape, and excitement (Hawes, 1988; Penington-Gray \& Kerstetter, 2001; Stone \& Nichol, 1999) may explain why the women were so impressed by the feminine comforts provided by the hotel.

Another dimension of female-travel that has been alluded to in past studies is the importance of friendship (Gibson et al., 2012; Hutchinson, Yarnal, Staffordson \& Kerstetter 2008; Son, Kerstetter, Yarnal \& Baker, 2007). Similar to the women in this previous work, the women who took part in the simulated girlfriend getaway emphasized that a central facet of these types of trips is to spend time with one another. Just like the women in Gibson et al.'s (2012) study, the chance to bond and to enjoy each other's company was more important than the type of activities they participated in. The unique dimension from the current study is the finding that hotel amenities and spaces can either facilitate or hinder the bonding experience. In particular the size 
of rooms, private or semi-private restaurant sectors, or even the availability of swimming pools later in the evening so that the women could just spend time together, were all noted as being important to their overall girlfriend getaway experience.

Consistent with previous work, some of the women in this study voiced concerns over safety and security issues in the hotel (Lutz \& Ryan, 1993; McCleary, et. al., 1994; Phadungyat, 2008; Sammons, et al, 1999). However, in the current study, the women also provide a more in-depth understanding about how psychological perceptions of safety frequently experienced by female travellers can be enhanced. They explained how the cards provided in their rooms listing the phone numbers to the hotel security made them feel more at ease. Moreover, the women also mentioned that they appreciated receiving information about places to go that were in safe areas as well as the car service provided to the shopping centre. At present, hotels provide information on numbers to dial for housekeeping, room-service and reception. This study suggests that this list of numbers should also include information on local emergency phone numbers as well as direct dial to someone who can answer any questions related to safety and security. These could cover issues such as safe means of transportation or safe locations around the area to sight-see, dine and explore. Past studies have included transportation to and from the airport as a preferred hotel service (Sammons, et al, 1999) and many hotels currently already offer this to their guests via regularly scheduled shuttle services. However, the women in this study discussed the need to extend this service to reliable and trustworthy transportation service catered specifically to their groups. Interestingly, in contrast to studies on female business travellers who identified as important specific hotel attributes such as dead bolt door locks or lighted hallways, (Lutz \& Ryan, 1993; Sammons, et al, 1999), only one group of women discussed these physical attributes. This finding warrants additional exploration. Are women travelling together less concerned about such measures compared to the female business traveller or even solo women travellers (Jordan \& Gibson, 2005; Wilson \& Little, 2005)? Perhaps the old adage of safety in numbers is at work among groups of women travelling together.

The last theme related to a specific activity of shopping and the provision of cash vouchers to facilitate this activity appears to have had contradictory consequences to those anticipated. While, shopping is frequently associated with female travellers (McGehee et al, 1996; Pennington-Gray \& Kerstetter, 2001; Smith \& Carmicheal, 2008) and also noted as an activity on girlfriend 
getaways (Gibson et al, 2012), in this study, the women appeared to be discontented, possibly not with the activity itself, but with the cash vouchers they were provided with. In particular, the difficulty for hotels managing such promotions is that it is often very difficult to match the store preferences of a group of women. Instead, the women in this study said that they would have preferred discount vouchers for services and activities that are more generic such as food i.e. restaurant vouchers or spa services. So perhaps the lesson here is that while cash vouchers may seem like a better deal, such giveaways may be filled with potential obstacles regarding guest brand preferences. On the contrary, discount vouchers could be a more feasible implementation in girlfriend getaway packages and promotions. It might also serve a hotel better to provide discounted access to their own amenities.

Thus, the findings from this study seem to suggest that female travellers are not homogenous and that there appear to be differences between women travelling for business and for pleasure. Another contribution of this study lies in its methodology. Past studies on women and travel needs have adopted a stated preference approach which might have been able to generate conclusive findings (Marzuki et al., 2012). However, these findings may not be readily applied to actual behaviour mainly because the choices observed are hypothetical. This study deliberately moved away from using hypothetical choice and the quantitative method of ranking and rating attributes in questionnaires. Consciously, we also chose to use an alternative approach to traditional interviews. Instead, this study adopted a pragmatic action research approach that involved five cyclical phases of data collection method that is based on a realistic setting, with interview questions concentrated on the amenities and services particularly catered to women who travel with other women. The research design involved multiple rounds of secondary data collection, two rounds of interviews with women who actually travel and had taken a girlfriend getaway, discussions with hotel managers, implementation of women-specific amenities in a girlfriend getaway package of a real hotel, and consultations with industry practitioners. Because each woman took part in one of three focus groups upon check out, we overcame the limitations of memory that are characteristic of retrospective studies. The pragmatic action research approach provided industry practitioners a means for preliminary testing of the feasibility of implementing a girlfriend getaway package in their hotels; as well as discovering important hotel attributes for women pleasure travellers that were previously obscure. The study actioned the change that women said they wanted in their accommodation, and provided a degree of 
confidence for practitioners to not 'wait-and-see' but implement feasible changes in their own properties. Therefore, a pragmatic action research approach may hold potential value for providing unique insights on other tourism and hospitality issues that require change and immediate action.

\section{Conclusion}

This study adopted a five-step pragmatic action research approach to explore and understand the accommodation experiences and preferences of all female travel groups. As a result, four themes were identified, two of which were consistent with previous findings on women travellers. The two new themes that emerged from the GGA respondents in this study touch on feminine comforts and shopping. Findings suggest that the needs of female leisure-travellers are distinct from those of women who travel on business. Recommendations for hotel management are made to enhance the GGA experience for women, notably providing spaces and activities to facilitate female bonding.

Although this study appears to have uncovered distinct differences between the hotel preferences of female business and leisure travellers, the next step would be to increase industry practitioners' confidence by establishing the representativeness of these findings across a larger sample of women using quantitative methods. To do this, women from Western and Asian countries who have been on girlfriend getaways need to be surveyed on the importance of preferred accommodation amenities, at the same time understanding how accommodation providers currently perform on the provision of these amenities. In this study, the focus was to explore the accommodation preferences of a new and under-researched market segment, the GGA so a group package product was put together to market to this segment. However, future studies could investigate the applicability of these findings to female leisure travellers in general. In addition, the women in the current study self-selected to participate via a Facebook competition and were also provided with a complimentary girlfriend getaway. As such, being selected as competition winners and being given a free vacation might have positively skewed their experience and their reports of it. However, all participants were asked how much they thought the package would be worth and their answers, which range between RM150 and RM220 per person, provide a benchmark for accommodation providers to consider implementing possible changes. Finally, the tourist activities that surfaced in this study may well be highly dependent on the destination, 
which in this case is an urban city. Future studies could target sand, sea and sun destinations, or rural eco destinations. 


\section{References}

Abbasi, A. S., Khalid, W., Azam, M., \& Riaz, A. (2010). Determinants of customer satisfaction in hotel industry of Pakistan. European Journal of Scientific Research, 8(1), 97-105.

Aitchison, C., Reeves, C., \& Jordan, F. (1998). Gendered (bed) spaces: The culture and commerce of women only tourism. In C. Aitchison \& F. Jordan (Eds.), Gender, space and identity: Leisure, culture and commerce (pp. 47-68). Brighton, UK: Leisure Studies Association.

Albayrak, T., \& Caber, M. (2015). Prioritisation of the hotel attributes according to their influence on satisfaction: A comparison of two techniques. Tourism Management, 46, 4350. doi: 10.1016/j.tourman.2014.06.009

Anderson, L. F., \& Littrell, M. A. (1995). Souvenir-purchase behavior of women tourists. Annals of Tourism Research, 22(2), 328-348. doi: 10.1016/0160-7383(94)00080-8

Arnould, E. J., \& Price, L. L. (1993). River Magic: Extraordinary Experience and the Extended Service Encounter. The Journal of Consumer Research, 20(1), 24-45.

Bartos, R. (1982). Women and travel. Journal of Travel Research, 20(4), 3-9. doi: $10.1177 / 004728758202000402$

Berdychevsky, L., Gibson, H., \& Poria, Y. (2013). Women's sexual behaviour in tourism: Loosening the bridle. Annals of Tourism Research, 42, 65-85. doi: 10.1016/j.annals.2013.01.006

Berdychevsky, L., Gibson, H. J., \& Bell, H. L. (2013). Girlfriend getaways and women's wellbeing. Journal of Leisure Research, 45(5), 602-623.

Birkett, D. (1989). Spinsters abroad: Victorian lady explorers. Oxford, UK: Blackwell.

Botterill, D., \& Platenkamp, V. (2012). Key concepts in tourism research. London, UK: SAGE.

Brownwell, J. (2011). Creating value for women business travelers: Focusing on emotional outcomes. Cornell Hospitality Reports, 11(12), 6-17.

Butler, K. L. (1995). Independence for western women through tourism. Annals of Tourism Research, 22(2), 487-489. doi: 10.1016/0160-7383(94)00101-4

Carson, D., Gilmore, A., Perry, C., \& Gronhaug, K. (2001). Qualitative marketing research. London, UK: SAGE.

Catterall, M., Maclaran, P., \& Stevens, L. (2000). Marketing and feminism: An evolving relationship. In M. Catterall, P. Maclaran, \& L. Stevens (Eds.), Marketing and feminism: Current issues and research (pp. 1-15). London, UK: Routledge.

Chan, P. (2014). A framework linking positioning strategy and resource-based view: Womenfriendly hotels. Web Journal of Chinese Management Review, 17(2), 1-22.

Chen, A., \& Peng, N. (2014). Examining Chinese consumers' luxury hotel staying behavior. International Journal of Hospitality Management, 39, 53-56. doi: 10.1016/j.ijhm.2014.01.002

Chen, L.-C., Lin, S.-P., \& Kuo, C.-M. (2013). Rural tourism: Marketing strategies for the bed and breakfast industry in Taiwan. International Journal of Hospitality Management, 32, 278 286. doi: 10.1016/j.ijhm.2012.07.005

Chen, W.-J., \& Chen, M.-L. (2014). Factors affecting the hotel's service quality: Relationship marketing and corporate image. Journal of Hospitality Marketing \& Management, 23(1), 77-96. doi: 10.1080/19368623.2013.766581 
Choi, T. Y., \& Chu, R. (2001). Determinants of hotel guests' satisfaction and repeat patronage in the Hong Kong hotel industry. International Journal of Hospitality Management, 20(3), 277-297. doi: 10.1016/S0278-4319(01)00006-8

Davidson, P. (1996). The holiday and work experiences of women with young children. Leisure Studies, 15(2), 89-103. doi: 10.1080/026143696375648

Deem, R. (1996). No time for a rest? An exploration of women's work, engendered leisure and holidays. Time \& Society, 5(1), 5-25. doi: 10.1177/0961463X96005001001

dos Santos, S., Chaves, M. S., \& Pedron, C. D. (2014). An analysis of open-ended online reviews about bed and breakfast and inns in Portugal. Revista Brasileira de Pesquisa em Turismo, 8(1), 99-119. doi: 10.7784/rbtur.v8i1.649

Ekiz, E., Khoo-Lattimore, C., \& Memarzadeh, F. (2012). Air the anger: Investigating online complaints on luxury hotels. Journal of Hospitality and Tourism Technology, 3(2), 96106. doi: 10.1108/17579881211248817

Enriquez-Magkasi, E. M., \& Caballero, R. T. (2014). Customer satisfaction and loyalty in Philippine resorts. International Journal of Social Sciences and Entrepreneurship, 1(9), 588-610.

Gibson, H. J., Berdychevsky, L., \& Bell, H. L. (2012). Girlfriend getaways over the life course: Change and continuity. Annals of Leisure Research, 15(1), 38-54. doi: 10.1080/11745398.2012.670963

Gibson, H. J., \& Jordan, F. (1998). Travelling solo: a cross-cultural study of British and American women aged 30-50. Paper presented at the fourth international conference of the Leisure Studies Association, Leeds, UK.

Greenwood, D. J. (2007). Pragmatic action research. International Journal of Action Research, $3(1+2), 131-148$.

Harris, C., \& Ateljevic, I. (2003). Perpetuating the male gaze as the norm: challenges for'her'participation in business travel. Tourism Recreation Research, 28(2), 21-30.

Hawes, D. K. (1988). Travel-related lifestyle profiles of older women. Journal of Travel Research, 27(2), 22-32. doi: 10.1177/004728758802700204

Huertas-Garcia, R., Laguna García, M., \& Consolación, C. (2014). Conjoint analysis of tourist choice of hotel attributes presented in travel agent brochures. International Journal of Tourism Research, 16(1), 65-75. doi: 10.1002/jtr.1899

Jeffreys, S. (2003). Sex tourism: Do women do it too? Leisure Studies, 22(3), 223-238. doi: $10.1080 / 026143603200075452$

Johansson, A. W., \& Lindhult, E. (2008). Emancipation or workability? Critical versus pragmatic scientific orientation in action research. Action Research, 6(1), 95-115. doi: $10.1177 / 1476750307083713$

Jones, D. L., \& Guan, J. J. (2011). Bed and breakfast lodging development in mainland China: Who is the potential customer? Asia Pacific Journal of Tourism Research, 16(5), 517536. doi: 10.1080/10941665.2011.597578

Jordan, F., \& Gibson, H. (2005). "We're not stupid . . But we'll not stay home either": Experiences of solo women travelers. Tourism Review International, 9(2), 195-211. doi: $10.3727 / 154427205774791663$

Kandampully, J., \& Suhartanto, D. (2000). Customer loyalty in the hotel industry: The role of customer satisfaction and image. International Journal of Contemporary Hospitality Management, 12(6), 346-351. doi: 10.1108/09596110010342559 
Kashyap, R., \& Bojanic, D. C. (2000). A structural analysis of value, quality, and price perceptions of business and leisure travelers. Journal of Travel Research, 39(1), 45-51. doi: $10.1177 / 004728750003900106$

Kerstetter, D., \& Pennington-Gray, L. (1999). Decision-making roles adopted by universityeducated women who travel for pleasure. Journal of Hospitality \& Leisure Marketing, 6(3), 23-39. doi: 10.1300/J150v06n03_03

Khoo-Lattimore, C., \& Ekiz, E. H. (2014). Power in praise: Exploring online compliments on luxury hotels in Malaysia. Tourism and Hospitality Research, 14(3), 152-159. doi: $10.1177 / 1467358414539970$

Khoo-Lattimore, C., \& Prayag, G. (2015). The girlfriend getaway market: Segmenting accommodation and service preferences. International Journal of Hospitality Management, 45, 99-108. doi: 10.1016/j.ijhm.2014.12.003

Khoo-Lattimore, C., \& Prideaux, B. (2013). ZMET: A psychological approach to understanding unsustainable tourism mobility. Journal of Sustainable Tourism, 21(7), 1036-1048. doi: 10.1080/09669582.2013.815765

Kinnaird, V., \& Hall, D. (1996). Understanding tourism processes: A gender-aware framework. Tourism Management, 17(2), 95-102. doi: 10.1016/0261-5177(95)00112-3

Lau, P. M., Akbar, A. K., \& Yong, D. G. F. (2005). Service quality: A study of the luxury hotels in Malaysia. Journal of American Academy of Business, 7(2), 46-55.

Lee, Y.-K., Jeong, Y.-K., \& Choi, J. (2014). Service quality, relationship outcomes, and membership types in the hotel industry: A survey in Korea. Asia Pacific Journal of Tourism Research, 19(3), 300-324. doi: 10.1080/10941665.2012.749930

Lewin, K. (1946). Action research and minority problems. Journal of Social Issues, 2(4), 34-46. doi: 10.1111/j.1540-4560.1946.tb02295.x

Lutz, J., \& Ryan, C. (1993). Hotels and the businesswoman: An analysis of businesswomen's perceptions of hotel services. Tourism Management, 14(5), 349-356. doi: 10.1016/02615177(93)90003-4

Malik, M. E., Naeem, B., \& Nasir, A. M. (2011). Hotel service quality and brand loyalty. Interdiciplinary Journal of Contemporary Research in Business, 3(8), 621-629.

Marzuki, A., Chin, T. L., \& Razak, A. A. (2012). What Women Want: Hotel Characteristics Preferences of Women Travellers. In M. Kasimoglu (Ed.), Strategies for Tourism Industry - Micro and Macro Perspectives (pp. 143-164). Croatia: InTech.

Mccleary, K. W., Weaver, P. A., \& Hutchinson, J. C. (1993). Hotel selection factors as they relate to business travel situations. Journal of Travel Research, 32(2), 42-48. doi: $10.1177 / 004728759303200206$

McCleary, K. W., Weaver, P. A., \& Lan, L. (1994). Gender-based differences in business travelers' lodging preferences. Cornell Hospitality Quarterly, 35(2), 51-58. doi: $10.1177 / 001088049403500218$

McEwan, C. (1996). Paradise or pandemonium? West African landscapes in the travel accounts of Victorian women. Journal of Historical Geography, 22(1), 68-83. doi: 10.1006/jhge.1996.0005

McKay, J., \& Marshall, P. (2001). The dual imperatives of action research. Information Technology \& People, 14(1), 46-59. doi: 10.1108/09593840110384771

Mohsin, A., \& Lockyer, T. (2010). Customer perceptions of service quality in luxury hotels in New Delhi, India: An exploratory study. International Journal of Contemporary Hospitality Management, 22(2), 160-173. doi: 10.1108/09596111011018160 
Nash, R., Thyne, M., \& Davies, S. (2006). An investigation into customer satisfaction levels in the budget accommodation sector in Scotland: A case study of backpacker tourists and the Scottish Youth Hostels Association. Tourism Management, 27(3), 525-532. doi: 10.1016/j.tourman.2005.01.001

Phadungyat, P. (2008). Factors influencing the selection of serviced apartments by female business travellers (Master's thesis, Srinakharinwirot University, Bangkok, Thailand). Retrieved from http://thesis.swu.ac.th/swuthesis/Bus Eng Int Com/Phatcharin P.pdf

Pruitt, D., \& LaFont, S. (1995). For love and money: Romance tourism in Jamaica. Annals of Tourism Research, 22(2), 422-440. doi: 10.1016/0160-7383(94)00084-0

Reason, P., \& Bradbury, H. (Eds.). (2001). Handbook of action research: Participative inquiry and practice. London, UK: SAGE.

Robinson, J. (1990). Wayward women: A guide to women travellers. New York, NY: Oxford University Press.

Ryan, M., Henley, N., \& Soutar, G. (1998). Gender differences in tourism destination choice: Some implications for tourism marketers. Paper presented at the Australian and New Zealand Marketing Academy Conference, Dunedin, New Zealand.

Sammons, G., Moreo, P., Benson, L. F., \& Demicco, F. (1999). Analysis of female business travelers' selection of lodging accommodations. Journal of Travel \& Tourism Marketing, 8(1), 65-83. doi: 10.1300/J073v08n01_04

Sinclair, M. T. (1997). Issues and theories of gender and work in tourism. In M. T. Sinclair (Ed.), Gender, work and tourism (pp. 1-15). London, UK: Routledge.

Small, J. (2005). Women's holidays: Disruption of the motherhood myth. Tourism Review International, 9(2), 139-154. doi: 10.3727/154427205774791645

Smith, M. (2013). "In her shoes": Victorian lady explorers in imperial Africa and their relationship to contemporary travellers in a commercialized, nostalgic landscape Providence, RI: Providence College, Department of History.

Stringer, E. T. (2013). Action research. Thousand Oaks, CA: SAGE.

Stumpf, T. S., Park, J., \& Kim, H. J. (2014). Appreciative and consumptive lodging attributes: Conceptualization and measurement. International Journal of Hospitality Management, 40, 71-80. doi: 10.1016/j.ijhm.2014.03.009

Swain, M. B. (1995). Gender in tourism. Annals of Tourism Research, 22(2), 247-266. doi: 0.1016/0160-7383(94)00095-6

Taylor, J. S. (2001). Dollars are a girl's best friend? Female tourists' sexual behaviour in the Caribbean. Sociology, 35(3), 749-764. doi: 10.1177/S0038038501000384

Timmermans, H., Molin, E., \& van Noortwijk, L. (1994). Housing Choice Processes: Stated versus Revealed Modelling Approaches. Netherlands Journal of Housing and the Built Environment, 9(3), 215-227.

Warnick, R. B., \& Chen, M. (2008). Female travel trends: A look back to the future. Tourism Review International, 12(2), 138-164.

Wilkins, H., Merrilees, B., \& Herington, C. (2009). The determinants of loyalty in hotels. Journal of Hospitality Marketing \& Management, 19(1), 1-21. doi: 10.1080/19368620903327626

Wilson, E., \& Little, D. E. (2005). A "relative escape"? The impact of constraints on women who travel solo. Tourism Review International, 9(2), 155-175. doi: $10.3727 / 154427205774791672$

Wilson, E., \& Little, D. E. (2008). The solo female travel experience: Exploring the 'geography of women's fear'. Current Issues in Tourism, 11(2), 167-186. doi: 10.2167/cit342.0 
Zhang, H. Q., Ren, L., Shen, H., \& Xiao, Q. (2013). What contributes to the success of Home Inns in China? International Journal of Hospitality Management, 33, 425-434. doi: 10.1016/j.ijhm.2012.11.002

Zhou, L., Ye, S., Pearce, P. L., \& Wu, M.-Y. (2014). Refreshing hotel satisfaction studies by reconfiguring customer review data. International Journal of Hospitality Management, 38, 1-10. doi: 10.1016/j.ijhm.2013.12.004 
Table 1: Participant Characteristics

\begin{tabular}{|c|c|c|c|c|c|c|}
\hline Pseudonym & $\begin{array}{l}\text { Foc } \\
\text { us } \\
\text { Gro } \\
\text { up } \\
\end{array}$ & Age & $\begin{array}{l}\text { Marital } \\
\text { Status }\end{array}$ & Ethnicity & Educational Level & Occupation \\
\hline Ping & \multirow{4}{*}{1} & 42 & Single & Chinese & Bachelor's Degree & Manager \\
\hline Veera & & 37 & Divorced & Indian & Bachelor's Degree & Admin Executive \\
\hline Sharma & & 32 & Single & Indian & Master Degree & $\begin{array}{l}\text { Senior Admin } \\
\text { Executive }\end{array}$ \\
\hline Stephanie & & 31 & Single & Chinese & Bachelor's Degree & Admin Executive \\
\hline Smitha & \multirow{4}{*}{2} & 28 & Single & Indian & Bachelor's Degree & Senior Executive \\
\hline Sze Man & & 35 & Married & Chinese & Bachelor's Degree & Senior Executive \\
\hline Rika & & 25 & Single & Malay & Bachelor's Degree & Admin Executive \\
\hline Azura & & 27 & Single & Malay & Pre-University & Admin Officer \\
\hline Christy & \multirow{4}{*}{3} & 22 & Single & Chinese & Bachelor's Degree & Operation Admin \\
\hline Ellie & & 22 & Single & Chinese & $\begin{array}{l}\text { SPM (equivalent to } \\
\text { the O-levels) }\end{array}$ & Student \\
\hline Lee & & 22 & Single & Chinese & SPM & Student \\
\hline Melissa & & 22 & Single & Chinese & SPM & Student \\
\hline
\end{tabular}

